\title{
REFERENCES
}

AtTMANNSPACHER, W., and HARTMANNSGRUBer, R. (1976), Some Results of 6 Years (1967-1972) of Regular Ozone Soundings at the Meteorological Observatory Hohenpeissenberg, FRG, Beitr. Phys. Atm. 49, 18-33.

Bojkov, R. D. (1969), Some Characteristics of the Total Ozone Deduced from Dobson-Spectrophotometer and Filter-Ozonometer Data and Their Application to a Determination of the Effectiveness of the Ozone Station Network, Ann. Geophys. 25, 293-299.

Crutzen, P. J. (1975), A Two-Dimensional Photochemical Model of the Atmosphere Below $55 \mathrm{~km}$ : Estimates of Natural and Man-Caused Ozone Perturbations due to NOx, Proc. 4th Conf. on CIAP, US Dept Transportation, 264-279.

DÜTSCH, H. U. (1969), Atmospheric Ozone and Ultraviolet Radiation, in: Climate of the Free Atmosphere (ed. D. F. Rex), 383-432.

DüTsCH, H. U. (1978), Vertical Ozone Distribution on a Global Scale, Pure appl. Geophys. 116, 511-529.

DÜrsch, H. U. (1979), Regular Ozone Soundings at the Aerological Station of the Swiss Met. Office at Payerne, 1972-1976, Lapeth-16, Zürich, 239 pp.

DütsCH, H. U., ZuluING, W., and LiNG, СH. (1970), Regular Ozone Observations at Thalwil, Switzerland and at Boulder, Colorado, Lapeth-1, Zürich, $279 \mathrm{pp}$.

DüTSCH, H. U., and LiNG, СH. (1973), Six Years of Regular Ozone Soundings over Switzerland, Pure appl. Geophys. 106-108, 1151-1168.

Labitzke, K. (1972), Climatology of the Stratosphere in the Northern Hemisphere, Part I: Heights, Temperatures and Geostrophic Resultant Wind speeds at 100, 50, 30 and $10 \mathrm{mb}$, Meteorol. Abhandl. 100.

London, J., Bojkov, R. D., Oltmans, S., and Kelley, J. I. (1976), Atlas of the Global Distribution of Total Ozone, July 1957-June 1967, NCAR/TN/113 + STR.

Mattana, N., Porra, G. P., and Serra, A. (1973), Cinq années de sondages ozone sur Cagliari, Pure appl. Geophys. 106-108, 1169-79.

OzONE DATA FOR THE WorLd, Atmospheric Environment Service, Canada Vol. 1-19.

Prrtock, A. B. (1974), Comments on Quasi-Biennial and Long-Term Fluctuations in Total Ozone, Monthly Weather Rev. 102, 84-86.

RIEHL, H. (1962), Jet Streams of the Atmosphere, Dept. atmos. Sci., Colorado State Univ., Colo., Tec. Rept 32,117 pp.

Wilcox, R. W., Nastrom, G. D., and Belmont, A. D. (1976), Periodic Analysis of Total Ozone and its Vertical Distribution, Proceedings Dresden Symposium, Aug. 1976, 26 pp.

(Received 24th January 1980)

\section{CORRECTED DATA}

While in press a recent correction in Bracknell's record was published in Ozone Data for the World, Vol. 20, in which the monthly means total ozone values for July, 1977 and 1978 is corrected to the new values 358 D.U. and 346 D.U. respectively. 